\title{
Popüler Sufiyane Mevizeciliğin Sembolik Söylemi Fazîlet-nâme Örneği
}

Yrd. Doç. Dr. AYDIN KIRMAN*

Öz

Edebî eseri uzun soluklu ve etkileyici kılan özelliklerden biri onun ifade vasıtası olan dilin niteliğidir. Din kültürü, felsefe ve bunlardan da beslenen pek çok öğreti, bazen edebî eser kıvamında sembolik anlatım üzerinden kalıcı olmayı tercih eder. Bu durumda bir öğretinin etki alanında bulunanların kendilerine özgü dil içi bir kavramlar listesi ve dillerini oluşturmaları doğaldır. Üretim aşamasındaki bu zihnî dizge, aynı zamanda popülerleşmek için farklı yorumlara ihtiyaç duyar. Bütün bunlar için de mevcut birikimde referans sayılan ana kaynakların dil, üslup ve ifade tecrübesi, bir yaygın eğitim modeli olarak taklit konusu olabilir. Bu çalışmada Yemînî'nin Fazîlet-nâme'si örneği üzerinden popüler sufiyane mevizeciliğin sembolik söylemi izlenerek kimin, neyi, nasıl ve niçin söz konusu ettiğine dair değerlendirmeler ve bazı teklifler ele alınacaktır.

Anahtar sözcükler: Yemînî, Fazîlet-nâme, popüler sufiyane mevizecilik, sembolik söylem, ideolojik masal.

\section{THE SYMBOLIC DISCOURSE OF POPULAR SUFI PREACHING THE EXAMPLE OF FAZÎLET-NÂME}

\section{Abstract}

One of the features that make the literary work impressive and long winded is quality of its language. Religious culture, philosophy and many discipline which feed from these, sometimes prefer to be permanent through symbolic discourse like literary work. In this case, it is normal for the other disciplines which are in sphere of influence of any discipline to make a specific and intra linguistic notions list and create a unique language for themselves. At the same time, this psychical system which is in progress, needs different interpretations to be popular. For all of this, language, style and expression experience of main resources which are considered as a reference in available accumulation, can be an imitation subject as a universal education model. In this work, symbolic discourse of popular sufi preaching will be followed on Fazîlet-nâme of Yemînî and evaluations and some offers about who mention what, how and why will be discussed.

\footnotetext{
* Muğla Sıtkı Koçman Üniversitesi Edebiyat Fakültesi Türk Dili ve Edebiyatı Bölümü, aydinkirman@gmail.com
} 
Keywords: Yemînî, Fazîlet-nâme, popular sufi preaching, symbolic discourse, ideological tale.

\section{Giriş}

- slâm mistisizmine dair herhangi bir kaynak, mutasavvıfların sadece "tasavvuf"

Tavramı konusunda bile herkesçe kabul gören bir tanım üzerinde

Luzlaşamadıklarını gösterir. Yüzlerce tanımdaki ortak tutum, tasavvufu dinî esasların dışına çıkarmamaya ve devrindeki yönetimlerle açıkça karşı karşıya getirmemeye özen gösteren bir meşrulaştırma çabası içinde kalmak üzerindedir. Zaten her tanım, onu dile getiren mutasavvıfın kendi iç dünyasında hâkim olan öznel mistik hâllerin ifadesidir. Tasavvufun ne zaman ve hangi kültür coğrafyalarında, hangi etkiler altında bir senteze dönüşmeye başlayıp yüzyıllar içinde devasa bir birikim meydana getirdiğine dair esaslı bir özete bakılırsa dahi (Ocak 1997: 6-10) kendisine has bir dil alanı oluşturmasının kaçınılmaz zarureti anlaşılabilir.

Dil, en basit tarifiyle insanlar arası anlaşmayı sağlayan bir vasıtadır, ancak var oluş, hiç bir gelişmiş dilin ifadesini karşılayamayacağı derecede aşkındır. Tasavvufun "irfanî hikmetler" şeklinde adlandırdığı kendi zihniyet ve telakkiler dünyasını aktarmak için de kendisine has bir dil ve anlatıma ihtiyacı bu yüzden ortaya çıkmıştır. Bu özel dil ve anlatımın gerekliliğinde yukarıda ifade edilen meşru kalma özeni olduğu kadar, irfanî hikmetlerin, buna hazır ve istidatlı olmayanlardan uzak tutulması önemli rol oynamıştır (Arpaguş 2005/2: 121-125).

Bir öğretinin meşru kalması ile onun toplumun her kesiminin istidatlı olanları tarafından eğitimde ilgi görüp kolayca benimsenmesi, gündelik dil ve anlatım seviyesinde mümkün görünse de bu çok kalıcı ve uzun ömürlü olmayacaktır. İnsanlığın ortak kültürel mirası sayılabilecek başyapıtlar uzun ömürlerini, söylemek istediğini aracısız ifade eden düz ve yalın üsluplu söylemleriyle değil; derin, geniş ve her çağ ve kültürün her seviyede az çok anlamlandırabildiği sembol ve imajlarla örülmüş edebî dile borçludurlar. Özellikle Sami dinlerinin kültür dilinde görüldüğü belirtilen sembolik anlatım ile bütün eski dünyanın din ve felsefesinin geniş kitlelere ulaştırılmasında başvurulan, "anlamı imajlar ve semboller aracılığıyla söze dönüştürülen en yüksek ve en mükemmel" dil ve anlatım hedeflenmiştir (Demirel 1012: 922).

"Sembol (Fr. symbole <Lat. <Yun.), bir fikir, düşünce, his vb.ni akla getiren, onu düşündüren işâret, resim, ses, harf, kısaltma vb. remiz, amblem, simge" dir (Ayverdi 2011: 1081). Nitekim duyularla ifade edilemeyen bir şeylerin somut kategoride belirtilmesi, "herkes tarafından kabûl edilen itibârî bir mânânın maddede sâbitleşmişs şekli"nin (Bilgegil 1989: 164), “sembolik” şeklinde kullanımı ise "simgesel”in anlaşılmasına yol açar. 
Sembolik dil veya anlatım çoğu dinlerin kültürlerinde ve edebî birikiminde yer almış bir anlatım yöntemidir. Bu anlatım tercihi, kısmen yanlış veya eksik anlama riskini de barındırır. Edebî sembol söz konusu olduğunda "itibârî mânânın maddede sâbitleşmiş̧ şekli" asla değişmez demek değildir. "Bu değişmenin ilk tezâhürü, itibârî mânânın sâbit olmaması, yazı yazanın ilhamına göre farklılık göstermesi sûretiyle karşımıza çıkar. Aynı şekilde ifade eden nesneden ifade edilen nesneye geçiş zaruri olarak işaret edilmediği için [...] sâdece ifadede sözü edilen nesne söz konusu imiş gibi görülecektir" (Bilgegil, 1989: 164-165). Bütün bunlar göz önünde bulundurulduğunda, remizlerle gizlenen anlam ve değeri bulup çıkarmak, çoğunlukla okuyucu / dinleyiciye ve bazen de müellifin kendisine düşebilmektedir. Sembol, alegori, metafor, istiare vb. kavramlaştırmaların bir edebî metnin doğuşundan başlayıp var oluş ömrü boyunca, art alanında mecazın, teşbihin hatta dolaylı anlatımın etkileri vardır. Nitekim bu kavramlaştırmaların anlam alanları, birbirlerine göre benzerlik ve farklılık yönünden ilgileri, ayrıca değerlendirmeyi hak eden bir mesaiyi gerektirmiştir (Demirel 2012: 917-921). Bazı kendine özgü inceliklerine rağmen yine de duygu ve düşüncelerin sembolik ve bir bakıma da örtük değerlerle inşası, ilgi çekmeye ve ortaya konan kültür varlığının her devirde farklı çevreler tarafından yeniden üretilmesine imkân tanır.

Burada ele alınan metinde hem teklik hem de çokluk hâliyle birer defa kullanılmış "remz" ve "rümûz" kelimeleri, "isteğini gizli yoldan, birtakım işaretlerle / anlamı kapalı sözlerle bildirme / anlatma" (Tulum 2013: 310) anlamina gelmektedir. Sembolü gelenekte rem(i)z ile karşılayan bu kavram, dolaylı anlatım biçimlerini ifade etmek dışında (Durmuş, 2007: 556-558) tasavvufun da özellikle itibar ettiği önemli anahtar kavramlardan biridir (Ceyhan, 2007: 558-560). İnsanlığın tarih ve kültür varlığında en güçlü sosyal kurumlar arasında yer alan din ve onun dili, yine onun gibi onun kılığında ve onunla birlikte hayat sürmek isteyen kültürel yorumu, “âdetâ paralel bir din” (Ocak 1997: 8) diliyle kendi kavram ve yaklaşım biçimlerini oluşturur. Nitekim mutasavvıflar insanları iki kısımda değerlendirmiş, kendi içlerinde psişik yolculuğun sonuna varanları "kâmil", yola yeni çıkan ve seyir hâlinde bulunanları "sâlik", ancak yola girmemişleri "henüz dalalette kalmış kimseler" olarak adlandırmışlardır (Levend 1984: 22). Özel bir yorumun örtük "cemaat" dilini çeşitli sebeplerle belirli bir zümre arasında tutmanın fazla bir zorluğu yoktur. Ancak bu müktesebatla geniş kitlelerde taban bulma ve onların dönüştürülmesi söz konusu olduğunda, pek tabii algı kapasitesi sınırlı kalabalıklara sembolik anlatımla seslenmenin güçlükleri ortaya çıkar. İslam kültür coğrafyasında pek çok alanda Kur'an'ın entelektüel üretimde ilham kaynağı olduğu kadar, eğitimde yöntem açısından da model alındığı (Koçak 2009: 187-215) bilinmektedir. Popüler sufiyane mevizeciliğin sembolik söyleminde de aynı 
yöntem ve hedeflerin izlendiği söylenebilir. Şu hâlde bu metin incelemesinde, kimin, neyi, nasıl ve niçin dillendirdiğine dair bir okuma tecrübe ve teklifi sunulacaktır.

XVI. yüzyılın ilk çeyreğinde kaleme alınmış olan Fazîlet-nâme, popüler sufiyane mevizeciliğin örnekleri bakımından zengin bir eserdir. Burada incelemeye esas alınan bir kesit ise sembolik söylemde teşhis ve intak sanatıyla bir hayvan hikâyesine yer vermesiyle, eserdeki diğer bütün malzemeden farklıdır. Tercüme oluşundan çok, müellifi olan Yemînî'nin yerelleştirici bazı ilaveleriyle telif tarafı daha ağır basan eserde, belki de anonim bir "fabl" in, sufiyane mevizecilikte kullanılmak üzere yazıya geçirilmiş olması son derece değerlidir. Metin incelemesine geçmeden önce müellifinin meşrebi hakkındaki bazı yayın problemlerine işaret etmekte fayda vardır.

İslâm Ansiklopedisi'ne göre "Yemînî, Kalenderî ve Bektaşî şairi"dir (Kırman, 2013: 420). Burada hemen belirtilmelidir ki sözü edilen yayında soyadı bile bir yazım yanlışlığının kurbanı olabilmiş bir madde yazarının bir başka yayınıyla kendi yazdıklarını tamir etmek zorunda kalması gibi bir durum, büyük bir talihsizliktir. Yemînî'nin Kalenderî-Kızılbaş tekke şairi olduğuyla ilgili kanaatleri güçlendirecek malzeme doğrudan Fazîlet-nâmesi'nde zaten bulunmaktadır. Onun, devrinden çok sonraları eserinden bağımsız bir şekilde aynı zamanda Bektaşî şairi kabul etmeye dair geleneksel yanlış kabuller ve tasavvufî meşrebi meselesi ise önceden uzun uzadıya tartışılmamış bir konu değildir (Kırman 2004: 67-97). Hatta yayını dört yıl geciken bir başka çalışmada meşrebine dair bu bilgi, yukarıda sözü edilen tartışmaya dayandırılarak kısaca tekrar edilmiştir (Kırman 2016: 120). Bu durumda, bir araştırmacının haklı ve geçerli ilmî bir gerekçe olmaksızın on iki yıl içinde kanaatlerini iki de bir değiştirmesi normal olmasa gerektir.

Hemen belirtilmelidir ki problem, İslâm Ansiklopedisi'ne 30.01.2009 tarihinde gönderilen "Yemînî" maddesi ile 2013 yılında yayımlanan metin arasındaki farklardan kaynaklanmaktadır. 43. Cilt araştırma dünyasının istifadesine ulaştı̆̆ı zaman, ne yazık ki İslâm Ansiklopedisi ilgili kurullarının, yazarın izin ve onayını almadan gönderilen metin üzerinde bazı tasarruflarda bulunduğu anlaşılmıştır. Buradaki talihsiz bilgi düzeltmelerinin evvel emirde 2016 tarihli çalışmada olmamasının sebebi ise yine bu yazının "Yemînî" maddesinin yayımlanmasından bir yıl önce teslim edilmiş olmasıdır. İslâm Ansiklopedisi'nde yazardan bağımsız bir şekilde muhteva düzenlemeleri sadece Yemînî́nin meşrebi konusunda değildir. "Yemînî" maddesinde, Faruk Sümer'in, Yemînî'nin “Eğribozlu olduğu [...] Tahtacılar'ın eser(in)e âdeta mukaddes bir kitap gibi değer verdiği”" (Sümer 2010: 437) kayıtları ile "Bibliyografya"da, madde yazarının kayıtlarında yer almayan bir bilgi tamamlanması yapılmıştır. Kaldı ki bu bilginin yer aldı̆̆ı "Tahtacılar" maddesi de Yemînî'nin Bektaşî olduğunu düşünmeyi özellikle zayıflatıcı bir muhtevaya sahiptir. 
"Yemînî" maddesindeki problemlerden ikincisi, şairin mahlâsıyla ilgili önemli bilgi özetine dair tartışmaların yazıdan çıkartılmış olmasıdır. Üçüncü problem, Yemînî’nin içinde bulunduğu geleneğin Bektaşîlerden ayrı olduğu (Ocak 2000: 45, 49-50), ancak çok sonradan Bektaşîlerce “aziz" sayılıp (Noyan 1998: 259-269) sahiplenildiğine dair değerlendirmeler, Charles Rieu'ye dayandırılmıştır. Hâlbuki burada açıklandığı gibi bu değerlendirmeler, aslında bir önceki iki ismin çalışmalarından çıkarılmış, sonuç itibariyle de Yemînî'nin yaşadığı devirde Bektaşîlik ile bir ilgisinin olmadığı belirtilmiştir. Bu kısımda söylenenler ile maddenin tanıtımındaki "Fazîletnâme adlı eseriyle tanınan XVI. Yüzyıl Kalenderî ve Bektaşî şairi" ibaresi birbiriyle çelişmektedir. Zira "Bektaşî şairi” olmak ile “...yaşadığı dönemden çok sonraları benzer bir senkretizme uygun olan ve XVII. yüzyıl başlarından itibaren Kalenderî zümrelerini de içine alan Bektaşî geleneğinin, mirasını devraldığı şairlerden biri” olmak arasında ciddi bir fark vardır. Hiçbir fani, özellikle göçüp gittikten sonra mirasçlarının meşrebine dâhil edilemez. Dördüncü problem, maddenin içinde herhangi bir şekilde adı geçmemekle birlikte madde metni deforme edildiği için "Bibliyografya"da, Ocak'ın çalışmasından hangi bakımdan yararlanıldığı muallakta kaldığı gibi, Noyan'ın eseri, metin içi atıf ve "Bibliyografya"dan tamamen kaldırılmıştır. Beşinci problem, gönderilen yazıda olduğu hâlde madde metninden çıkarılmış bulunan ve gerçekte esas Rieu'ye dayandırılan kısa değerlendirme ise şöyle olmalıdır: “Charles Rieu, Yemînî’nin hayatının geleneğin şehirli tezkire yazarları tarafından bilinmemesini, Sünnîlik ile irtibatlı biyografi yazarlarının, onu Şîิ temayülleri yüzünden tanımadıklarına bağlayan bir sebeple izah eder." (Rieu 1888: 172-173)

İslâm Ansiklopedisi'nde "Yemînî" maddesindeki diğer öz bakımdan çok fazla bozulmamış, bazen özetlenmiş tasarruflar bir yana bırakılacak olursa, yukarıda sıralanarak tashih edilen hususlardaki sorumluluk, hiç bir şekilde kabul edilemez. Ancak üç yıllık bir süre içerisinde ilk fırsatta bunlara dikkat çekip araştırma dünyası için gerekli uyarı ve düzeltmeleri yapmamış olmanın elbette haklı ve geçerli bir mazereti ile savunulabilir tarafı da yoktur.

Yemînî'nin Fazîlet-nâmesi'nden, bu çalışmada incelemeye esas alınacak ve beyit numaralarının aralıkları alıntıların sonunda parantez içinde gösterilecek metin (Tepeli 2002: 504-509), "Fasl” başlıklı olup toplamda 75 beyittir. Aruzun Mefâ'îlün Mefâ'îlün Fe'ûlün vezniyle nazmedilmiş bulunan mesnevi metni, ilk 26 beyitlik kısmı itibariyle muhtelif konularda nasihatler, 32 beyitlik kısmı tahkiye, 12 beyitlik kısmı ise tahkiye ile bağlantılı açıklama ve nasihatler olmak üzere üç ana yapıdan oluşur. Metinde girişteki genel nasihat konularından tahkiyeye geçiş ve bağlantıyı sağlayan tek beyit büyük ihtimalle müellife ait olmakla birlikte muhtelif nüshalarda tahkiyeyi kesip birbirinden tamamen farklı yama gibi ve elbette anlatıcının metne gereksiz bir müdahalesi gibi görünen ikinci tek beytin, metnin 
esasına aidiyeti şüphelidir. Nihayet metin, sözü edilen bu üç kısımlık faslı, eserin bütününe eklemleyen üç beyitlik bağlantı ifadeleriyle son bulur. Metindeki aslî uzunluklar dışında ünsüzlerden sadece "ayın" ve "hemze"nin gösterilmesiyle yetinilmiş, bugünün Türkçesine zaman zaman açıklamalı ve serbest dil içi aktarım yolu tercih edilmiştir. İki bölümde ele alınacak olan incelemede ilk önce metnin ana hatlarıyla yapı özelliklerine göre kısımlarının dil içi aktarımı, sonra da genel değerlendirmeler yer alacaktır.

\section{Bugünün ve Devrinin Diliyle Mevize}

Fazîlet-nâme' deki bu "Fasl", eserin yazıldığı dönemin okur-yazar Türkçesinin halk seviyesindeki manzum dilidir. Mevizenin ilk kısmı, insanın iç ve dış varlığı ile eşya arasındaki ilişkilerin dinî-tasavvufî "derin” anlamları üzerine düşünmeye çağrıdır.

\subsection{Düşünmeye davet}

İnsan, gönlünün isteklerini bulsa ne hoş olurdu. Ancak gönlün istekleri kolayca bulunursa, insan bunun kıymetini bilmez. Zamanlarca eziyet çekip incinmeyen Tanrı'ya vefa göstermeye uymaz:

“Ne hoşdur dil murâdın bulsa insân

Velî kadrini bilmez bulsa âsân

Zamânlar çekmeyen cevr ü cefâyı

Ri'âyet idemez Hakk'a vefâyı"' (5972-5973)

Yemînî, muhataplarına cihan sevgilisi için eziyet çekmemeyi öğütler. Çünkü dünyevî olan hiç bir şeyin er veya geç vefası olmaz. Kişi eğer gerçek vefalı bulmak istiyorsa, gece gündüz çalışıp kendine yâr olmalıdır. Eğer insan kendi kendisine yâr olmazsa, hayatı ve ölümü bilemez. Ölümden diriliği fark etmeyen canlara, İlahî bir feyz olarak kâinatın sırlarını bilme kudretine sahip olan kimseler, insan demezler:

“Cihân yâri-yiçün çekme cefâ hîç

Anun yokdur vefâsı ir ü ger giç

Eger bulam disen gerçek vefâdâr

Gice gündüz dürüş gendüne ol yâr

Eger gendüzüne yâr olmayasın

Hayâtundan memâtun bilmeyesin

Ölümden dirliği fark itmeyen cân

Dimezler ehl-i 'irfân ana insân”' (5974-5977)

Yerin ve gögün hesaplarını bilmeyenler, bu açılamalardaki manası gizli sözleri nasıl anlayacaklardır? İnsan bu dünyaya niçin geldiğini ve Yaratıcı Zât'ın sıfatlarının delillerini nasıl bileceğini anlamalıdır:

"Hisâbın bilmeyen arzun semânun

Kaçan anlar rumûzın bu beyânun 
Neye geldün bu mülke anla zâtun

Delilin nice bilürsin sıfâtun" (5978-5799)

İnsan, felekler döndükçe ömrün boşu boşuna geçeceğini, cisimler ve suretlerin toprak olacağını bilmelidir. İşte o zaman bu ruhun hâli ne olacak, bu gönül ferahlıklarının sırrı nasıl keşfedilecektir? Eğer bütün bunlar bilinebilirse insan, hatta baştanbaşa, uçtan uca can olunabilir:

“Geçer 'ömrün 'abes döndükçe eflâk

Bilürsin cism ü sûret olısar hâk

Ne olur hâli ol dem işbu rûhun

Nice keşf ola sırrı bu fütûhun

Eger bildünise insân olursın

Serâser uçdan uca cân olursın" (5980-5982)

İnsan, el, ayak, göz, kulak, dudak gibi suretlerin işaretlerinden sırları fark etmelidir. Aksi takdirde bütün bu suretler kişinin gerçeği örtme suçuna şahitlik edeceklerdir:

"Bu sûretden bu elden bu ayakdan

Bu gözden bu kulakdan bu dudakdan

Bu sırdan fark kilmazsan 'alâmet

Virürler küfrüne bunlar şehâdet" (5983-5984)

İnsanın bunca hizmetçisi varken Şeytana kul olması için hiç bir sebep yoktur. İnsan madem baştanbaşa insan özelliklerini göstermektedir, kesin bilgilerden habersiz olması kabul edilemez. İnsan bu kılıktayken şüpheden uzaklaşmazsa, seçkinler nazarında eşekten farkı kalmaz. Hâlbuki eşek otlağını da bilir, su içeceği yeri de. Yazıklar olsun ki insan, bir de "adam" adını takınmıştır.

“Variken bunca hizmetkâr sende

Sebeb ne olasin seytâna bende

Çü hey'et serbeser insân-sıfatsın

Yakînün bilmege bî-ma'rifetsin

Irag olmazısan bu tonda şekden

Havâsda olmayasın fark eşekden

Eşek otlagını bilür suvadın

Hayıfdur sen urundun âdem adın" (5985-5988)

Yemînî, iddialarına eserinin bir başka yerinde yer verdiği (Tepeli 2002a: 477) "men lâ edebe lehû ve lâ 'ilme lehû (kimin edebi yoksa ilmi de yoktur)" hadisini de kısmî iktibas yoluyla delil getirerek uyarılarını sürdürür. Söz ilmini okuyanlarla kastettiği kesime, belli ki bunlar bazı özellikleri bakımından devrinin olumsuz tiplerinden kadı ve/veya müftülerdir (Kırman 2016: 127-130), işte "men lâ..." (hadisi), Allah sahtekârlığa rıza göstermez, der. Oysa böylesi okumuş sahtekârlar, pek çoklarının öldürülmesine rüşvet karşılığı hüküm vererek kana girerler. Bunlar, müftü adını takınıp fetva verirler, ancak Müslümanlık evinde de delik 
açmışlardır. Hâlbuki bu ahmaklar, çalışıp ilmi ve aklı kullansalar, dilleri boş işlere hak demese, daha iyidir. Dinin aslı kendisinden gelen Tanrı Resulü, ona selam olsun, “Ölmeden önce ölünüz. Hesaba çekilmeden de kendinizle hesaplaşınız" buyurmuştur. İnsan daha sorulmadan hesabını verebilmeli, çabalayarak "Necat Ehli"ne, yani kurtulmuşlar arasına kavuşmalıdır. Eğer Hz. Muhammed elinden tutarsa, kişi ancak o zaman sonsuza kadar Cennet bağında kalabilir. Kişi, hesabını dürüst vermezse o son günü ve o gündeki azabının hazır olduğunu daima hatırlamalıdır:

“Okudun 'ilm-i kâli zihî men lâ

Degül telbisüne râzî o Mevlâ

Nicenün katline fetvâ virürsin

Alursın rişvetin kana girürsin

Virüp fetvâ dakındun nâm-ı müftî

Müselmânlıkda düzdün hâne süfti

Dürüş bir 'ilmi kullan ‘aklı ahmak

Ki dimeye dilün bâtıl işe hak

Ne buyurdı işit Tanrı Resûli

Ki andan irdi bu dînün usûli

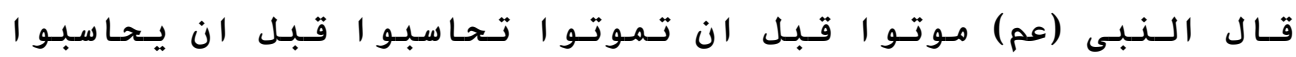

Sorılmadın hisâbun viregörgil

Necât ehline cehd it iregörgil

Ki sana destgîr ola Muhammed

Kalasın bâg-1 cennetde mü'ebbed

O âhır güni yâd it kim hisâbun

Dürüst virmeyesin hâzır 'azâbun” (5989-5996)

\subsection{Kurt ile tilki hikâyesi}

Yemînî, mevizesinde merkeze aldığı insanı, kendi içiyle dış dünyası arasındaki ibret verici ilgiler üzerinde düşündürme çabasını bir hikâye ile daha somut hâle getirmeyi uygun görmüş olmalıdır. Nitekim eğer remzini bilip düşünerek anlarsan sana bir söz (hikâye) anlatacağım, uyarısıyla mevizede tahkiye tekniğine geçiş yapar:

"Sana bir söz diyeyin anlarısan

Eger remzin bilüp fehm eylerisen" (5997)

Zamanında koyun güdüp çobanlık eden bir kişi vardır. Sürüsünü çoğaltmak için bir yerde yurt tutmuştur. Ancak kuzularına musibet bir kurt dadanmıştır. Sonunda canı iyice yanan çoban, kurda içinde bir tutam peynir bulunan tuzak hazırlar:

"Zamân içre meger varıdı bir er

Koyun güder çobânıdı bürâder

Meger döl almağa tutmışıdı yurd 
Kuzusına dadanmış bir yaman kurd

Çobân acıdı kurdı kurda bir dâm

Kodı bir baş peynîr dâma encâm" (5998-6000)

O sırada bir tilki oraya gelir, gözü peynire ve tuzağa ilişir. Tuzağın etrafında dolanıp gezinir, bir süre de uzaktan bakıp karışmadan çevresini izler. Tilki, kendi kendine "bu peyniri ortalık yere bırakmanın tedbir dışı olduğu"nu mırıldanır. "Bu peyniri alırsam, tuzak beni yakalar ve başıma pek çok iş gelir", der. Tilki, tuzaktan korktuğu için peynire dokunmaz, ancak bir süre uzaktan seyretmekten de kendini alamaz:

“O dem bir dilkü irdi ol makâma

Gözi tuş oldı peynîre vü dâma

Revân tolandı dâmun devresini

Biraz seyr itdi turdı çevresini

Didi gendüye dilkü işbu peynîr

Bunı yâbânda komak gayr-1 tedbîr

Alursam ben bu peynîri tutar dâm

Gelür başuma çok dürlü serencâm

Penîre degmedi korkdı duzakdan

Varup seyr eyledi bir dem uzakdan" (6001-6005)

Bir süre sonra tilki gezerken musibet kurda rastlar, önünde yalanıp abartılı bir coşku gösterisinde bulunur. İşte o zaman da kurt, tilkiye "bu ne hâl, ne diye sevinç gösteriyorsun, bir şey mi var?" diye sorar:

“Gezerken dilkü o kurda olur duş

İleyinde yalandı eyledi cûş

Didi kurd ol dem i dilkü nedür hâl

Neden şâdî kılursın nedür ahvâl" (6006-6007)

Tilki, "niye sevinip gülmeyeyim, iyice doydum" der. Kurt da ona "sevgili dostum, neden doyduğunu söyle, açlık beni hasta etti" der:

“Didi dilkü nice şâd olmayayım

Katı toydum nicesi gülmeyeyim

Didi kurd ana neden toydun i yâr

Haber vir beni açlık kıldı bîmâr" (6008-6009)

Tilki, “falanca ovaya gidince, orada gökten peynir yağdığını gördüm. Eğer gönül rahatlığı ve saflığına sahipsen, peşimden gel. Şuracıkta, seni oraya götüreyim de karnını doyur" diye devam eder:

"Didi dilkü fülân sahrâya vardum

Semâdan anda peynîr yagdı gördüm

Safân varısa gel ardumca uygıl

Yakındur ilteyim karnun toyurgil" (6010-6011) 
Kurt, "ey dost, lütuf gösterip beni oraya iletirsen sana yüz binlerce minnet duyarım" der. Tilki de "uygundur" diyerek kurdu kendine uydurur, ona kılavuz olup onu tuzağa ulaştırır. Peyniri kurda gösterir, ancak kendisi biraz geniş bir yerde durmayı ihmal etmez. İyice acıkmış olan kurt, çok geçmeden peyniri görür:

“Didi kurd sad hezârân minnetüm var

Beni anda ilet lutf eyle i yâr

Revâdur diyüp uydurdı vü gitdi

Kılavuz oldı ol dâma iletdi

Penîri gösterüp gin yerde turdı

Acıkmış kurd hemân peynîri gördi" (6012-6014)

Kurt, gözünü karartarak peynire ulaşınca ağzıyla peyniri, aynı anda tuzak da çenesinden ve göğsünden geçerek kurdu başından kavrar. Bu sırada peynir de uzağa fırlamıştır. Anlatıcı bütün bu peş peşe hareketlilik arasında, kurdun çobana çok zararı olduğunu da hedef kitleye hatırlatmayı ihmal etmez. Bu tür bir müdahale, Ahmed Midhat Efendi'nin, modern anlatıcılık tekniklerine geçiş sürecinde bile, o çok bilinen kendi varlığını okuyucusuna hatırlatma tarzını andırır. Nitekim pek çok nüshada bulunmadığından metnin aslına ait olup olmadığı şüpheli görünen, muhtemelen sonradan eklenmiş tek beyitlik daha esaslı bir müdahalede de "şahım, kişi ettiğini bulmaz sanma, cihanın oyununa inanma" uyarisı yer alır:

"Gözin kararduban peynîre irdi

O dem kim karvayup ağzını urdı

Hemân karvadı dâm kurdı başından

Geçüp çengâl çenesinden döşinden

Penîr sıçradı ağzından yabâna

Ziyânı çog irişmişdi çobâna

Gişi itdügini bulmaya sanma

Cihânun lu'bına şâhum inanma" (6015-6018)

Tilki, tuzağın kurdu yakaladığını görünce, çok geçmeden peynire doğru koşar, peyniri kaptıktan sonra daha emniyetli bir mesafeye çekilir. Kurt, tuzakta çaresiz bir şekilde kalmıştır:

“Çü dilkü gördi duzak tutdı kurdı

Hemân peynîrün üstine yügürdi

Aluban peynîri çıkdı kenâre

Duzak içinde kaldı kurd bi-çâre" (6019-6020)

Kurt, tilkiye ağlayıp inleyerek "Ey dost, sonunda beni neye uğrattın? Beni yok edici bu düşmanlığının sebebi neydi ki? Ey çetin hileci, senin baştan çıkarmanla işin sonunda içine düştüğüm bu dert nedir? Elimde fırsat varken derini yırtıp boğazını dişlemedim de... Eğer zamanında seni yağmalasaydım, bu aşağılanma başıma gelmeyecekti" der: 
“Didi kurd dilküye aglayuban zâr

Neye ugratdun âhır beni i yâr

Neyidi bana bu kahrıla kînün

Beni kurtar eger varısa dînün

Ne derddür ben ki düşdüm âhır-1 kâr

Senün igvânılan i saht-ı mekkâr

Variken elde fursat işlemedüm

Derin yırtup bogazun dişlemedüm

Eger itseyidüm vaktüni gâret

Bana gelmezidi işbu hakâret" (6021-6025)

Peyniri yiyen tilki, kurda "Sen bu kadarcık derdin incinme olduğunu söyleme. Bu kadarcık şey için kafa karışıklığı gereksiz. Asıl, tuzağın sahibi gelince iş belli olur. Çobanın ne kadar kuzularını yemiştin... O zamanlar vücudun semirir, canın rahatlardı. Çoban bunların hesabını senden bir bir soracaktır. Şimdi esas başına geleceklerin öncesini bırak, sonrasının tedbirini düşün" der:

"Yiyüp peynîri dilkü didi kurda

Cefâdur dime sen bu denlü derde

Bu denlü nesne-yiçün çekme teşvîş

Duzagun issi gelince olur iş

Ne denlü kuzısın yidün çobânun

Tenün semrür safâ alurdı cânun

Sorusardur hisâbın sana bir bir

Önüni ko sonunı eyle tedbîr" (6026-6029)

Yemînî, kötü fiillerin fâili kurdun bela tuzağında inleyip ağlayarak acizlik içinde kaldığını ve artık bir cevap veremediğini söyleyerek mevizesinin tahkiye kısmını sonlandırır:

"Cevâba 'âciz oldı gürg-i bed-kâr

Kalup dâm-1 belâda 'âciz ü zâr"' (6030)

\subsection{Hikâyedeki semboller}

Yemînî, "ey dost" diye seslendiği hedef kitlesine hikâyedeki sembolleri açıklar. Buna göre, kurt tamahkâr nefis, tilki de tamahkâr nefsi ayartan şeytanın şeytanıdır. Kimin yol göstericisi iblis olursa, alçaklık itibarsızlık tuzağı içinde kalır. Kişi eğer aklı bırakıp nefsine uyarsa, tuzağa kapılmış kurda döner:

“Yakîn bil kurdı nefs-i tâmi” i cân

Nedür dilkü ana vesvâs-1 şeytân

Anun kim mürşidi iblîs olısar

Mezellet dâmı içinde kalısar

Koyup 'aklı eger nefse uyarsin 
Duzag içindeki kurda dönersin" (6031-6033)

Yemînî, mevizeyi hikâyesinde yer almayan sembollerden de faydalanıp kısmen genişleterek açıklamalarını sürdürür. Aşırı istekler, gönül kuşuna yem olursa, insan tuzağa düşüp ziyana uğrar. Akıl ise din yolunun önderi, bütünüyle kesin bilgi sahiplerinin doğru yolu gösterenidir:

“Dilün murgına şehvet olsa dâne

Duzaga düşüp irersin ziyâne

'Akıl kim pîşvâ-yı râh-ı dîndür

Tamâmet mürşid-i ehl-i yakîndür" (6034-6035)

Hâlbuki cihan arzuları tilki gibidir. Doğru yolu bilenler, ona uymazlar. Kişi hırslı oluşa kapılmamalı, tamahkârlık çengeline yakalanmamalı, onun tuzağına düşmemelidir. İnsanın görevi, tuzağın sahibini bilerek O'ndan sakınmak, çalışıp çabalayarak nefsini güçsüzleştirmek ve edebini korumaktır. Oysa irade, nefsin eline verilirse, nefsin arzuları dini de dünyayı da yağmalar:

“Cihân ârzûları misl-i rubâhî

Uyar mı bilen ana togru râhı

Harîs olup bunun dâmına düşme

Tama' çengâlınun kâmına düşme

Hazer eyle duzagun issini bil

Edep sakla dürüş nefsün zebûn kıl

Yed-i nefsüne virürsen irâdet

İder dünyânı vü dînüni gâret" (6036-6039)

İnsan, eğer içindeki emredici fiilleri öldürür, dört ayaklı hayvanlardakine benzer ihtiraslarının boynunu vurursa, başı düşkünlük tuzağına yakalanmaz ve içi dışı gönül saflık ve mutluluğunun nuruyla dolar. Kurtuluşa ermişlerin üzerinde uyuştukları şey, cihanın boşanılması gereken yaşlı bir kadın olduğudur:

“Eger emmâre fi'lin öldüresin

Behâyim hirsınun boynın urasın

Mezellet dâmına irmeye başun

Tola nûr-1 safâ içünle taşun

Budur ehl-i necâtun ittifakı

Cihân bir pîrezendür vir talâkı" (6040-6042)

Yemînî, mevizesinin burada ele alınan faslını, kendine seslenen telkinler ve nihayet faslın esas eserin bütünüyle bağlantısını sağlayan beytiyle sonlandırır. Her hâlde mevizeye muhatap olanlara göre kendini de nasihatten muaf saymayan veya kendi nasihate muhtaç tarafını bu şekilde hedef kitleyle eşitleyen Yemînî, “Sözü azalt, uzatma. Açıklamayı iç yüzüyle kıvamında bırak, iddiacı olma. Cihanın bulaşıcılığını terk edip arınmış, maddî sıfatlardan da kaçınıp onlara mesafeli ol " der. Farsça mensur Fazîlet-nâme'nin esas 
müellifinden "Üstad" diye saygıyla bahsederek orijinal eserdeki 18. "Fazîlet"e geçeceğini haber verir:

\author{
“Yemînî sözi az eyle uzatma \\ Beyânı ma'nî kıl da'vî gözetme \\ Cihân âlâyişinden geç berî ol \\ Heyûlâyî sıfatdan kaç geri ol \\ İdelüm on sekiz fazl üzre bünyâd \\ Ne vechile beyân itmişdür üstâd" (6043-6045)
}

\title{
2. Mevize Üzerinde Genel Değerlendirmeler
}

Mevizedeki konusu edilen nasihatler ana hatlarıyla şöylece toparlanabilir: İnsanın dünyevî arzularına emeksiz veya kolayca ulaşması, vefasız olmasına yol açar. Arzulanan her şeyin de esasında vefası yoktur. İnsan kendi iç ve dış varlığı üzerinde düşünmeli, hayat ve ölümü iyice anlamalıdır. Ölüm ve hayatı dert etmeyen gamsız cahillere insan denmez. Bütün var oluş bazı hesaplara bağlıdır. Bu hesaplara dair gizli sırlar, Allah'ın sıfatlarının da delilleridir. Zamanın akıp gitmesi ve bu arada her şeyin değişmesi, insana mutlaka kendi akıbetini de düşündürmelidir. Gerçekte kelimenin ideal anlamıyla insan olmak ve büsbütün kozmik bilinç kesilmek ancak böylece mümkün olabilir. Hiç kimse kendisini yalnız zannettiği zaman bile bir başına değildir. Kişinin sahip olduğu her şey, eylem ve söylemlerinin tanıklarıdır. Hayvanlar nasıl içgüdüsel olarak kendi ihtiyaçlarının gereğinde doğalarına uygun davranabiliyorsa, insan da kendisine yakışır bir tutumu sürdürmeli, asla şeytanlaşmamalıdır. Cahillik ve gamsızlık ne kadar insanı insanlıktan çıkarırsa, salt söz ilminin sözcülüğünü yapmak da aynı değerdedir. Söz ilminin kazandırdığı ayrıcalık ve mevkileri istismar edip bundan nemalanırken kitabına uydurup diğer insanların canlarına bile kastedenler, bildikleri ile hayat tarzlarını uyumlu hâle getirmeyen "edep"siz zalimlerdir. Pek tabii bunların içinde bulundukları durum, dinin özüne aykırıdır.

Temel fikirler bakımından ortalama dinî-tasavvufî telkinler gibi görünen bu nasihatlerin, kitleler üzerinde etkili ve kalıcı olması için bütün mevizeye hâkim bir sembolik söylem içerdiği bellidir. Yine mevize içinde tahkiyeye başvurup onda dahi bazı sembolikleri devreye sokma tekniğinin hem profesyonel, hem de faydacı amaçları olsa gerektir. Bu amaçların daha berrak anlaşılabilmesi için metinde açıkça "remz" oldukları ima edilen veya edilmeyen, diğer taraftan daha derin anlamları konusunda imasına gerek duyulmayan sembolleri de değerlendirmekte fayda vardır.

Mevizenin tahkiyeye geçmeden çeşitli konulardaki nasihat ve tartışmalar içinde "Mevlâ" kelimesine kafiye düşürülmek üzere kullanılmış "men lâ" ibaresi, daha önceden sehven "molla" anlamıyla karşılanmış (Tepeli 2002b: 418) olsa da, metindeki remizlerden en örtük durumdaki hâliyle dikkat çekmektedir. Yemînî'nin gerçekte iktibasla işaret ettiği "men 
lâ..." hadisinin ilk kelimeleri olan bu ibare, belli ki mevizelerin ruhanî yaşantısına aşina olan hedef kitlelerce anlaşılabileceği için veya eserin başka yerlerinde izah edilmiş olduğundan sadece adlandırmayla yetinilmiştir. Mevize içinde yukarıda da dikkat çekildiği gibi bu ibarenin işaret ettiği anahtar kavramlardan biri "ilim" ise de, diğeri ilmin varlık ve geçerliliğine ön şart olan "edep"tir.

Yemînî, kısaca "edepsiz ilim olmaz" şeklinde ifade edilebilecek bu söylemde, edebin ilmin ön şartı olmasının hikmetini, "ebced" hesabıyla izah edip delillendirmekten geri durmaz. Buna göre, "edeb" kelimesinin ( ا د ب ) harflerinden "Elif"in sayı değeri 1, "Dâl" 4 ve "Bâ" 2' dir. Basitçe bunlar toplandığ1 vakit "seb 'a'l-mesânî (yani, “tekrarlanan yedi)"yi işaret eder (Tepeli 2002a: 478; Kırman 2004: 501-502). Aslında Kur'an'ın 15/87. ayetinde "seb'an min el-mesânî..." olarak geçen bu ibarenin, müfessirlerin çoğunca yedi ayetten ibaret Fâtiha Sûresi kabul edildiği ve Türk edebiyatında Hz. Muhammed'in yüzüyle ilgili unsurlardan sayıldığı (Yeniterzi 1993: 108) bilinmektedir.

Birbirini haber veren bu ve benzeri remizler yoluyla 7 sayısına ulaşmak, hedef kitleye Hurufîlerle birlikte onların mirasını devralanların “Ümmü'l-kitâb (Kitabın, yani “Kur'an'ın anası)" gördükleri Fatiha'nın ortaya koyduğu temel nasların dış anlamını takdis etmeyi kazandırabilir. Öte yandan algı ve meşrebe göre 7 sayısının işaret edildiği "seb'a'l-mesânî" ve/veya "edep" kavramı yoluyla geçmişte bu sayı üzerinden çeşitli hesaplarla (Gölpınarlı, 1989: 18-19) dış dünyaya Bâtıni yorumlar üzerinden katıksız Hurufî gözlerle bakmanın esrarlı kapısı açılmış olur. "Seb'a'l-mesânı̂", modern dünya için artık birer fantezi gibi karşılanan Hurufî “te'vil”lerindeki Bâtıni arka planın açığa çıkartılmasında anahtar bir göstergedir. Bu sebeple hiç bir şekilde Hurufiliğin inanç dünyasıyla bağlantısı olmadığı hâlde gelenekte yaygınlaşmış bu ve benzeri sembollere yer verenlerden şüphelenilmesi, böylesi potansiyel birikim ve mirasın bakiyesidir.

Tipik bir harf simgeciliği örneği olan edep remzinin bu metindeki kullanımı hakkında son olarak şunlar söylenebilir: Metindeki söyleme göre, "edepsiz olanların ilmi de yoktur" prensibinden hareketle, sadece ilmiyle amel etmeyenler değil, edebin remzini bilmeyen, Bâtıni yorumlarına değer vermeyenler de "dalâlette kalmış kimseler" olarak görülmektedir. İşte zaten bu mantıktan hareketle Yemînî, kendi hedef kitlesinin dışında gördüğü ve mesafeli durduğu kadı ve müftülerin, yani bir bakıma "ulemâ-yı rüsûm"un işaret edildiği devlet bürokrasisi ve âlimler topluluğunun, hukuksuz işler yapmasını edepsizlik olarak görür. Onlara karşı en keskin hücumlarla söylem geliştirmesinin arkasında, onların aynı Bâtıni geleneğin çerçevesi içinde yer almamalarının da rolü büyük olmalıdır (Kırman 2004: 501; 2016: 127-130).

Mevize içinde hikâye anlatarak önceden sıralanmış nasihatlerin daha somut bir çerçevenin olay örgüsü içinde ele alınmasının, sembollerle verilen telkinlerde kalıcılık ve 
etkililikle yakından ilgisi olsa gerektir. Anlatıcının belli ki her birini remiz olarak gördüğü bu sembollerden kurt, tamahkâr nefsi temsil ettiği gibi, tilki de elbette kurnazlığ bakımından şeytanın (da) şeytanı rolündedir. Diğer taraftan kurdun temsil ettiği rol, aynı zamanda tamahkâr nefsin azgınlaştırdığı ve özellikle "ilmiyle âmil" sayılmadığından hak ettiğinden fazlasıyla çok gelire karşı zaaf duyan ihtiraslı "ulemâ-yı rüsûm"un, örtük bir şekilde ifade ve yerilmesinde araçtır. Tilki, ayartıcı dünyevî arzuları, peynir dünyanın cezbedici haz ve lezzetlerini, tuzak da aslında işlevi gereği, göründügünden farklı olan ve fıtratı "muzır" kesimleri yakalamaya yarayan birer eşya olarak maddî dünyanın vitrinini temsil eden figür ve dekorlardır.

Hikâye içinde hedef kitle için ayrıca açıklanmasına gerek duyulmamış sembollerden zaman zaman kurda yem olmuş kuzuların da dâhil olduğu sürü ile bunların hepsinin sahibi olan çobanın da birer remiz olması pekâlâ düşünülebilir. Otlak anlamına gelen "mer'a"daki sürü, metnin telif zamanının söz varlığındaki "bir hükümdar idaresi altında bulunan ve vergiye tabi halk" anlamında, çoğulu "re'âyâ" olan "ra'iyyet" kavramını da hatırlatır. Arapça aynı kelime kök ailesinin "ra'y" mastarından, "güden" anlamını karşılayan "râ'î" kavramı da çoban olduğuna göre, hikâyedeki çoban "döl almak" için "yurt tutmuş" basit bir çobandan öte, aynı zamanda politik bir figür ve "tek" insandır. Çoban, yurt tutması, sürüyü çoğaltması, sürüsünü görüp gözeterek beslemesi, onları korumak için tuzak kurması, sürüye dâhil olmayan "muzır" yaradılışlıları cezalandırması bakımlarından Allah değilse bile onun sıfatlarının tecellisi olan “zıllu'llâhi fî'l-'âlem (Allah'ın yeryüzündeki gölgesi)” gibi bir üst konumu temsil etmektedir. Duruma bu açıdan bakıldığında kurt ve tilkinin, meşruiyet dairesinin dışındaki suç potansiyeli yüksek vahşileri ve bir bakıma ötekileri, sürünün ise dairenin içindeki evcil ve itaatkâr mazlum cemaati temsil edişi arasında çok keskin bir tezat vardır. Hikâyenin kurgusunda bu sembollerin başarılı bir şekilde konumlandırılıp yergi ve mizah unsurlarılla donatılmış olması, bu mevize "Fasl" ındaki satirik muhtevaya sahip hikâyeyi de benzerleri gibi “ideolojik bir masal” hâline getirir (Kırman 2007: 20-21).

Benzer bir kurgu ve sembolik anlatıma yer veren tarihî-edebî metinlerden XV. yüzyıl şairi Germiyanlı Şeyhî'nin Har-nâme'sini de bu özellikleriyle kısaca hatırlamak, her iki metnin muhtevasının daha anlaşılır hâle gelmesine yardımcı olabilir. Şeyhî'nin Harnâme'sindeki hikâye kahramanı eşek, mağdur ancak cahil kara kalabalıkları, "pîr" eşek ise aynı halk içinden çıkmış, tuzu kuru olduğu kadar konum ve birikiminin hakkını vermeden durumunun keyfini süren kurnaz "ulema” yı temsil eder. Öküzler "ümera” yı, tarla sahibi ise tıpkı burada ele alınan metindeki tek insan gibi “zıllu'llâhi fî’l-'âlem”, devrin padişahıdır. İki satirik hikâye karşılaştırıldığında, Har-nâme'deki sembolleştirmenin evcil hayvanlar vasıtasıyla yapılmasına karşılık, Fazîlet-nâme'de hem evcil, hem yabani hayvanların kullanıldığı görülmektedir. Har-nâme' de devrin bütün toplum yapısını veren "sürü", evcil 
hayvan sembolleriyle kabaca "meslekler" üzerinden temsil ettirilmiştir. Bu ahenkli toplum yapısı, her bakımdan aç ve hasta eşeğin bir ara tehlikeli sorular peşinden "yağma" ve "talan" suçuna bulaşmasıyla bir sosyal ritim bozukluğu tehlikesi geçirse de, suçlunun ibretlik bir şekilde cezalandırılması ile sistem ideal yapısına tekrar dönmüş görünür. Şeyhî’nin hikâyesi tarım ekonomisine dayalı, yerleşik ve neredeyse yarı şehirli sembolizmi ile oluşturulmuş, muhatabı politik hiyerarşinin en kudretli ve "kâmil" insanı sayılan devrin padişahı olduğundan en üst konumdaki makama sunulmasıyla dikkat çekici özelliklere sahiptir.

Fazîlet-nâme' de ise toplum yapısı bir vaiz dervişin algısına göre şekillenmiş, belirli telakkileri paylaşan cemaat (yani "sâlik"ler topluluğu durumundaki) "sürü" ile "dalalette kalmış" vahşi hayvanların temsil ettiği ötekiler (müellifinin yaklaşım ve adlandırmasıyla "Haricîler" de denebilir,) olmak üzere kabaca ikiye ayrılmıştır. Sembolleştirmeler ise "iyiler" ve "kötüler"in kalın çizgilerle belirlendiği "meşrepler" üzerinden yapılmıştır. Bu hikâyede de "cinayet" ve "yağma" suçları birikmiş olan kurt, önünde sonunda mutlaka tuzağın sahibi tarafından cezalandırılacak, hikâyedeki sosyal ritim bozukluğu düzeltilip ideal yapıya kavuşulacaktır. Yemînî'nin hikâyesindeki çoban, "kâmil” bir insan sıfatı ve adaleti sağlayıcı yetkisiyle elbette tuttuğu yurdun "manevi" padişahıdır. Fazîlet-nâme'deki hikâye, hayvancılık ekonomisine yaslanan taşralı sembolizmi ile oluşturulmuş, muhatabı ise devrin her bakımdan kenarda kalmış, ücrada yaşayan sıradan insanların oluşturduğu kapalı cemaat yapısıdır. Şeyhî, resmî doktrinin hem uzağında hem de gerisinde kalmış "ulema"nın durumunu, devrin padişahına şikâyet edip toplumun zihniyet çarpıklığı ve iktisadi dengesizlik konusunda "memduh"unu devrinin tanığı ve vicdanı olan aydın sorumluluğuyla kibarca uyarır. Yemînî ise cemaatine, görevini yağmacı kurtlar gibi istismar eden "ulema" yı hedef gösterip resmî doktrine paralel moral değerleri diri tutarak manevi padişah adına taşranın çileli insanlarına umut ve adalet vadeden bir vaaz verir. Her iki şairin anlattıklarındaki ortak payda ve beklenti, tüm zamanların ekmek ve su kadar aziz bildiği “adalet" vurgusudur. Bütün bunlardan da anlaşılacağı üzere, "merkez"de nasıl bir "nizamintizam" inşasında ısrar varsa, "kenar" da da temelde benzer, üslup ve bakış açısı farklı bile olsa "paralel", kendi içinde istikrarlı bir sistemde ısrar vardır.

Yemînî'nin mevizesindeki kötüler arasında yer alan hikâye figürlerinden kurt ile tilkinin kısa bir süre de olsa meşruiyet dışı ve hak etmedikleri bir nimete çökmeden önce bir işbirliği içinde görünmeleri sıradan bir ayrıntı gibi görülebilir. Ne var ki sahte bir samimiyetin eseri olan bu dostluğun arkasında dolandırıcılık yoluyla elde edilecek çapul ganimetinin elde edilmesi hesabı vardır. Ganimete birlikte ulaştıklarında gizli niyetler açığa çıkar. Kötüler, birbirlerine de kötülük etme istidadına sahiptirler. Teşhis ve intak sanatına başvurulmasaydı, modern dünya için bir hayvan belgeselinden kesitler olabilecek bu görüntülerin başarılı tasviri, herhâlde keskin ve çok dikkatli bir gözlemin ürünü ve 
gerçekçiliği muhataplarına da hissettirmeyi hesaplaması yönüyle modern zamanların kamera tekniğini andırmaktadır. Tilkinin peynirle ilk karşılaştığı andaki şaşkınlığı, ihtiyatkârlığına rağmen ortalık yerdeki nimetin cazibesinin bir süre onu bırakmaması, kararsızlık içinde bir süre peynirin çevresinde pervane olması, sonra vazgeçmiş gibi oradan geçici bir şekilde uzaklaşmasına dair ayrıntılar sadece dikkatli bir gözlemin değil, belirli bir hayvan psikolojisinin tasvirindeki başarının da göstergesidir. Kurtla karşılaşınca takındığ nimete doymuş, hayırsever ve hoppa dostluk rolü de mizahi bir üslupla sahnelenmiştir.

Tilkinin ayartıcı yeteneğine karşılık, kurt kandırılmaya teşne düz bir figürdür. Bu mevizedeki kurdun, metnin telif zamanından çok daha eski Türk destanlarında dardaki topluma yol göstericilik eden mitolojik liderlerin remzi durumundaki kurda ait zerrece bir çağrışım barındırmadığı görülmektedir. Bilindiği gibi modern zamanlarda 30 Aralık 1925'te kabul edilen 701 sayılı "Mevcut Evrâk-1 Nakdiyenin Yenileriyle İstibdâline Dair Kanun" gereğince tedavüle sokulan banknotlardan 5 TL'lik banknotun ortasında, Ankara Kalesi önünde "Halâskâr" Gazi Mustafa Kemal ve Türklüğün remzi, koşan bir bozkurt figürü ve sağında Birinci Meclis binası yer almaktaydı. Sözü edilen banknotların baskısı harf inkılabından önce gerçekleştirildiğinden para üzerindeki rakam ve yazılar Osmanlı harfleriyle Türkçe ve devrin uluslararası moda lisanı Fransızca yazılmıştı. Bütün bunlar sembollerin devirden devire değişebildiği, anlam ve çağrışım sürekliliğinde zaman zaman kopma ve kesintiler olabildiğini göstermektedir.

Fazîlet-nâme' deki kurdun, modern zamanların ideolojik saiklerle yeniden hatırlayıp tekrar tedavül ve üretime dâhil ettiği eski Türk mitolojisiyle hiç bir ilgisinin olmadığ anlaşılmaktadır. Mevizedeki kurt, kandırılma konusunda fazla çaba harcatmayan muhteris talancıların sembolü, aç gözlülüğüyle ters orantılı bir şekilde de tilkinin dostluğundan şüphelenmeyecek derecede akıl fukarasıdır. Nitekim klasik Türk şiirinin realist kaygılar gütmeyen çağdaşı farklı meşreptekilerin metinlerine göre bu mevizedeki akıl vurgusu da gözden kaçırılmayacak şekilde dikkat çekmektedir. Akıllı davranmamanın dramatik sonuçları, kurdun tuzağa yakalanmış hâliyle çarpıcı bir şekilde resmedilmiştir. Kurdun düşünüp duraklamadan ok gibi tuzaktaki peynire hamle yapması, tuzağın onu yakalamasıyla aynı anda peynirin uzağa fırlaması, tilkinin yine de tedbirli davranarak biraz uzakta peyniri yemeye koyulması vb. sıralı hareketler ilgi çekicidir. Bütün bunların, hedef kitle tarafından iyi fark edilmesi bakımından önce yavaş çekim, her şeyin bir anda olup bitmesini vermek bakımından ise hızlandırılmış anlık görüntülerle okuyucu/dinleyici muhayyilesini yeterince besleyici tasvir kudretini gösteren sahneler olduğu açıktır.

Tilki ile kurt aynı menfaat hedefi için bir süreliğine birlikte yoldaşlık etmiş figürlerdir, ancak oyunun son sahnesinde biri diğerini kendi yararına kapana kıstırıp zekâsının meyvesini hasat ederken kimin aslında ne olduğu hakkındaki sır da ortalığa saçılmış olur. 
Kurdun içinde bulunduğu acıklı durum, onun yakın geçmişe dair hayıflanmaları arasında tilki hakkındaki esas niyetini de açığa çıkarır. Tilki ne kadar hain ve art niyetliyse, aslında kurt da eline fırsat geçse tilki hakkında hayırlı niyet ve düşüncelere sahip olmadığı gerçeğini ifşa eder. Bütün bunlar o anın tartışmalarıdır ve içinde bulunulan durumun, kimin daha hain ve/veya kudretli olduğunun, hele ahlak ve vefa tartışmalarının artık sonucu değiştirmeye bir katkısı olmayacaktır. Buna benzer bütün tartışmalarda olageldiği gibi, tilki çok yakın geçmişin hayıflanmalarını dinleyip tartışmaya tahammül edemez. Eğer bir geçmiş tartışılacaksa daha eski sabıka kayıtları ortadadır. Şimdiden geçmişe bakıp eseflenmenin sonuca hiçbir etkisi yoktur. Esas mesele, "şimdi"den sonrasıdır. Herkes yapıp etmelerinin er veya geç mutlaka hesabını verecektir.

\section{Sonuç}

$\mathrm{Bu}$ çalışmada ele alınan metinde işaret edilen "remz" ve "rümûz" kelimeleri, “sembol"ü gelenekte karşılayan bir kavramdır. Bu kavramların ifade ettiği teknik, tasavvufun da özellikle başvurduğu söylem tarzlarından biridir. Dinin herhangi bir özel yorumunun örtük "cemaat" dilini, belli çekincelerle belirli bir zümre arasında tutmak kolaydır. Geniş kitlelerde taban bulma ve kitlelerin psikolojik açıdan dönüştürülmesi söz konusu olduğunda, pek tabii algı kapasitesi sınırlı kalabalıklara sembolik anlatımla seslenmenin verimli, etkili, kalıcı ve sürükleyici yollarını tercih etmek gerekir. İslam kültür coğrafyasında pek çok alanda Kur'an'ın, entelektüel üretimde ilham kaynağı olmasına benzer bir şekilde, eğitimde de yöntem açısından model alındığı anlaşılmaktadır. Popüler sufiyane mevizeciliğin buradaki sembolik söyleminde de aynı yöntem ve hedeflerin izlendiği söylenebilir.

Buna göre, mevizenin hitap ettiği hedef kitlenin, hem ikna hem de inandırma yoluyla metnin zihniyet evreni için eğitildiği anlaşılmaktadır. Bu eğitim sürecinde hedef kitle ile çok kolay temas kurulabilecek bir dil seviyesi tercih edilmiştir. Ele alınan konular, rafine edilmiş çarpıcı ifadelerle hedef kitlenin kolay anlayabileceği bir kıvamda tutulmuştur. Sırf kuru ve öğretici nasihatler olmaması için genel konularla uyumlu, meseleyi sahiplenmeyi kolaylaştırıcı vasıtalardan biri olarak tahkiyeye başvurulmuştur. Moral değerlerin özenilecek model davranış kültürü hâline getirilmesi için ibretlik durumları belirginleştiren zıtlıklara yer verilmiş, böylece kurguda karşıtlık da sağlanmıştır. Bu özellik, estetikte zıtların birlik ve dengesi prensibine uygundur. Anlatımda olabildiğince insanî güdü ve duygular tahrik edilerek hedef kitlenin kazanılması son derece profesyoneldir. Bütün zihnî faaliyetlerin akışı boyunca yüceltilip yerilen değerler listesi oluşturma, mevizenin amaçlarıyla uyum sağlar.

Mevize, hitap ettiği insanların duygusal, zihinsel ve düşünsel potansiyelini sevk, idare ve kontrol maksadıyla insan aklı ve vicdanına aynı anda seslenmede başarılıdır. Bütün metin 
boyunca maksadı en iyi ve etkili ifade yolları yoklanmıştır. Son derece geniş, derin ve kapsamlı konular özlü söyleyişler ve halk üslubuyla maksada uygun hâle getirilmiştir. Anlatımın etkileyici ve ilgi çekici olması için hedef kitlenin zaman zaman dikkatinin çekilmesi ihmal edilmemiştir. Hitap edilen insan çevresinin alg1 ve bilinç seviyesine göre her hâlükârda işe yarar bir çeşitliliğge yer verilmiştir. Soyut öğretinin somut hâle dönüştürülmesinde kurguya yer verildiği kadar, kurgudan elde edilecek telakkilere rasyonelleştirilmiş bir taban oluşturulmuştur. Tahkiyedeki gerçekçi tasvirler kurgunun etki kudretini sağlamlaştırmış, kurgu da telakkilerin kalıcılık ve sürekliliğini sağlamıştır. Metin, büyük ölçüde yöntem bakımından taklit ettiği Kur'an'ın eğitsel yönüne öykünürken, diğer yandan ona yaklaşma, onunla var olma, ondan güç almak üzere atıflarda hem ayete hem de hadise yer vermiştir, böylece din kültürünün kendi amaçlarına uygun müktesebatından yararlanmıştır. Ele alınan konular, hayattan büsbütün kopuk somut fikir ve inançlar olmayıp insan duyguları, hayattaki duruşu ve varlığıyla ilgili olduğundan, akıl vurgusu ve kendince gerçekçilik tarzıyla yaşanılan hayatla güçlü bağlar da kurmuştur.

$\mathrm{Bu}$ mevizede amaçlarına uygun semboller, anlatımı somutlaştırıcı bir teknik, tezat ve gerilimi cirmine göre yüksek çatışma, gerçekçi ve güçlü tasvirler, uygun dozda mizah ve yergi, iyilik ve kötülüğü kışkırtıcı bir üslupla ayrıştırma ve buna bağlı hikâye öncesi ve sonrası konuyla ilgili nasihatler son derece profesyonel bir çabanın ürünüdür. Mevize, farklı zamanların farklı algı düzeylerindeki insan kesimlerine de, alabileceği kadar ibret dersleriyle her devrin kendine özgü şartlarında temelde benzer vaka örneklerini güncelleştirilebilir okuma fırsat ve imkânlarını vermektedir.

\section{Kaynakça}

Arpaguş, Sâfi (2005/2). “Tasavvufta 'Mantıku't-tayr', Mevlânâ' da Hz. Süleyman ve Kuşdili

Tasavvuru". M. Ü. İlâhiyat Fakültesi Dergisi. 29. İstanbul: s. 121-135.

Ayverdi, İlhan (2011). Misalli Büyük Türkçe Sözlük. İstanbul: Kubbealtı.

Bilgegil, M. Kaya (1989). Edebiyat Bilgi ve Teorileri (Belâgât). İstanbul: Enderun.

Ceyhan, Semih (2007). “Remiz". DIA. C. 34. İstanbul: Türkiye Diyanet Vakfı Yayınları. 558560.

Demirel, Şener (2012). “Sembol, Sembolik Dil ve Bu Bağlamda Mesnevî’nin İlk 18 Beytindeki Sembolik Unsurlar". Turkish Studies International Periodical For The Languages, Literature and History of Turkish or Turkic. Volume 7/3. Summer. Ankara: 915-947.

Durmuş, İsmail (2007). “Remiz”. DİA. C. 34. İstanbul: Türkiye Diyanet Vakfı Yayınları. 556558.

Gölpınarlı, Abdülbâki (1989). Hurûfîlik Metinleri Kataloğu. Ankara: AKDTYK Türk Tarih Kurumu Yayınları. 
Kırman, Aydın (2004). Yemînî'nin Fazîlet-nâme'si -Şekil ve Muhtevâ Tahlili-. Yayımlanmamış Doktora Tezi. İzmir: Ege Üniversitesi. 67-97.

Kırman, Aydın (2007). “Harnâme'yi Eski Türk Edebiyatı'ndan Okumak”. Değirmen (Eğitim, Düşünce ve Sanat Dergisi). Adapazarı: 19-29.

Kırman, Aydın (2013). "Yemînî”. DİA. C. 43. İstanbul: Türkiye Diyanet Vakfı. 420-421.

Kırman, Aydın (2016). “Yemînî'nin Fazîletnâme'si ve Nâbî'nin Hayriyye'sindeki Tarihî Olumsuz Tipler: Sufi ve Kadı". Ölümünün 300. Yılında Nâbî'ye Armağan. Ankara: TDK Yayınları (Yayıma Haz.: İ. Çetin Derdiyok; H. Dilek Batislam). 117-135.

Koçak, Süleyman (2009). “Kur'ân'da Mesellerle Anlatımın Eğitim Açısından Değeri”. Dinbilimleri Akademik Araştırma Dergisi. Samsun: IX. S. 1. 188-215.

Levend, Agâh Sırrı (1984). Divan Edebiyatı -Kelimeler ve Remizler, Mazmunlar ve Mefhumlar-. İstanbul: Enderun.

Noyan, Bedri (1998). Bütün Yönleriyle Bektâşîlik ve Alevîlik. ?: Şahkulu Sultan Dergâhı-Ardıç Yayınları. C.1.

Ocak, Ahmet Yaşar (1997). "İslâm, Tasavvuf ve Tarikatlar (Sosyal tarih perspektifinden bir bakış)". Türkiye Günlü̆̆̈̈̈. Ankara: S. 45. 5-10.

Ocak, Ahmet Yaşar (2000). Alevî ve Bektaşî İnançlarının İslâm Öncesi Temelleri. İstanbul: İletişim Yayınları.

Rieu, Charles (1888). Catalogue of The Turkish Manuscripts in The British Museum. London.

Sümer, Faruk (2010). “Tahtacılar”. DİA. İstanbul: Türkiye Diyanet Vakfı. C. 39. 436-437.

Tepeli, Yusuf (2002a). Derviş Muhammed Yemîn̂̂ Fazîlet-nâme I (Giriş-İnceleme-Metin). Ankara: AKDTYK Türk Dil Kurumu Yayınları. 504-509.

Tepeli, Yusuf (2002b). Derviş Muhammed Yemînî Fazîlet-nâme II (Gramatikal Dizin). Ankara: AKDTYK Türk Dil Kurumu Yayınları.

Tulum, Mertol (2013). Osmanlı Türkçesi Büyük El Sözlüğ̈̈. İstanbul: Kap1 Yayınları. 1. bask1. Yeniterzi, Emine (1993). Divan Şiirinde Na't. Ankara: Türkiye Diyanet Vakfı Yayınları. 